\title{
HUBUNGAN DUKUNGAN SOSIAL DAN PENYESUAIAN DIRI PADA MASA PENSIUN PEJABAT STRUKTURAL DI PEMERINTAHAN PROVINSI BALI
}

\author{
Cokorda Istri Mirah Jayanti Biya dan Luh Made Karisma Sukmayanti Suarya,S.Psi., M.A. \\ Program Studi Psikologi, Fakultas Kedokteran, Universitas Udayana \\ cokistrimirahjayantibiyaa@yahoo.com
}

\begin{abstract}
Abstrak
Penyesuaian diri merupakan faktor yang penting bagi pensiunan. Penyesuaian diri merupakan bentuk tingkah laku yang ditujukan untuk menanggulangi kebutuhan yang ada di dalam diri individu. Tujuan penyesuaian diri adalah untuk mendapatkan keharmonisan antara tuntutan dari dalam diri dan lingkungan dimana individu tersebut berada. Untuk mendapatkan penyesuaian diri yang baik pada masa pensiun sangat diperlukan dukungan sosial. Dukungan sosial mengacu pada memberikan kenyamanan, merawat dan menghargai. Pejabat struktural identik dengan fasilitas pelayanan yang memadai, adanya asisten, relasi dan pendapatan tinggi yang mengakibatkan keterkaitan antara dukungan sosial dan penyesuaian diri pada masa pensiun akan sangat nampak pada Pegawai Negeri Sipil (PNS) pejabat struktural yang sudah pensiun di Pemerintahan Provinsi Bali. Penelitian ini bertujuan untuk mengetahui hubungan dukungan sosial dengan penyesuaian diri pada masa pensiun pejabat struktural. Subjek yang digunakan adalah pensiunan pejabat struktural di Pemerintahan Provinsi Bali, usia 57 hingga 58 tahun. Jumlah sampel pada penelitian ini berjumlah 105 . Reliabilitas skala dukungan sosial adalah 0,910 dan reliabilitas skala penyesuaian diri pada masa pensiun adalah 0,894 . Hasil uji normalitas variabel dukungan sosial adalah 0,200 dan variabel penyesuaian diri pada masa pensiun adalah 0,052 . Hasil uji linearitas variabel dukungan sosial dan variabel penyesuaian diri pada masa pensiun adalah 0,000 . Metode analisis yang digunakan adalah analisis korelasi pearson product moment. Hasil uji korelasi dalam penelitian ini adalah $0,717(\mathrm{p}=0,000)$. Berdasarkan hasil penelitian terlihat bahwa ada hubungan yang positif dan signifikan antara dukungan sosial dengan penyesuaian diri pada masa pensiun pejabat struktural di Pemerintahan Provinsi Bali. Memiliki arti semakin tinggi dukungan sosial, maka semakin tinggi pula penyesuaian diri masa pensiun pejabat struktural.
\end{abstract}

Kata kunci: dukungan sosial, penyesuaian diri, masa pensiun

\begin{abstract}
Personal adjustment is an important factor for retirees. Adjustment is kind of behavior that aims to respond the individual needs. The purpose of personal adjustment is to obtain well becoming between personal demand and the environment where the individual lives. In order to get better personal adjustment in retirement, it really needs social support. Social support refers to provide comfort, taking care and appreciating. The structural officer is identical with adequate service facility, the presence of assistants, the relations and high income, which is cause the relationship between social support and personal adjustment in retirement is highly visible on the structural officer of Civil Servants (PNS) in Bali Province Government who has retired already. This research aims to determine the relationship between social support and personal adjustment in the retirement of structural officer. The subject of this research is structural officer who has retired already and worked in Bali Province, age range is 57-58 years old. Total subjects in this study is 105 persons. Reliability of social support scale is 0.910 and the reliability of retirement personal adjustment scale is 0.894 . Normality of social support is 0.200 and normality of personal adjustment in retirement variable is 0.052 . Linearity test is 0.000 . Analysis methods in this research is pearson product moment correlation. The result of correlation test is $0.717(\mathrm{p}=0.000)$. Based on the result, it shows that there is relationship between social support and personal adjustment in the sstructural civil servants of government in Bali Province. Its mean the higher the sosial support, the higher the adjustment to retirement.
\end{abstract}

Keywords: social support, personal adjustment, retirement 


\section{LATAR BELAKANG}

Bekerja merupakan kegiatan yang dilakukan untuk memenuhi kebutuhan hidup sehari-hari, sehingga individu dapat mencapai apa yang dikehendaki. Dengan bekerja individu dapat memenuhi kebutuhan fisik yang membutuhkan sandang, pangan dan papan selain itu bekerja juga akan memenuhi kebutuhan individu dengan rasa aman, tenteram, dan kepastian tentang hari-hari yang akan datang. Individu yang bekerja juga dapat memperoleh kehidupan yang lebih baik (Suardiman, 2011). Menurut Isnawati \& Suhariadi (2013), pekerjaan dapat menjadi sumber harga diri bagi individu, karena individu yang memiliki pekerjaan di mata individu lain dianggap mandiri dan dapat memenuhi kebutuhan sendiri.

Masa bekerja yang dialami individu adalah tahap perkembangan karir yang dimulai dari fase pengembangan karir, penentuan karir, pemantapan karir, pembinaan karir, sampai pada tahap kemunduran. Tahap kemunduran merupakan tahap terakhir dalam berkarir yaitu individu menghadapi masa akhir kerja dan memasuki masa-masa pensiun. Setelah masuk pada masa pensiun individu harus menemukan pola hidup baru karena telah melepaskan jabatan sebelumnya (Super dalam Baruch, 2004). Schwartz (dalam Hurlock, 1980), menyatakan bahwa masa pensiun merupakan akhir dari pola hidup individu dalam bekerja atau dapat pula disebut sebagai masa transisi ke pola hidup yang baru. Pensiun selalu menyangkut perubahan peran, perubahan keinginan dan nilai, dan perubahan secara keseluruhan terhadap pola hidup setiap individu.

Dalam menghadapi masa pensiun, individu umumnya mengeluarkan berbagai macam reaksi. Secara garis besar ada tiga sikap ataupun reaksi yang umumnya muncul ketika individu memasuki masa pensiun yaitu menerima, terpaksa menerima, dan menolak. Sikap penolakan terhadap masa pensiun umumnya terjadi karena individu yang pensiun tidak mau mengakui bahwa dirinya sudah harus pensiun, takut tidak dapat

memenuhi kebutuhan-kebutuhan tertentu, takut kehilangan peran sosial di masyarakat, kehilangan kekuasaan, kontak sosial dan harga diri rendah (Rakhmat \& Budiman, 2010)

Gejala lain yang juga dapat muncul saat individu memasuki masa pensiun adalah gejala post power syndrome. Post power syndrome adalah gejala yang umum terjadi pada individu yang sebelumnya mempunyai kekuasaan atau menjabat satu jabatan, namun ketika sudah tidak menjabat lagi, seketika itu terlihat gejala-gejala kejiwaan atau emosi yang kurang stabil. Post power syndrome secara umum muncul akibat individu hidup di dalam bayang-bayang kebesaran masa lalu dan kurang mampu memandang realita yang ada saat ini (Eliana, 2003).
Di Indonesia, reaksi-reaksi yang muncul ketika memasuki masa pensiun juga dialami oleh individu yang dalam hal ini adalah PNS. Salah satu kasus yang berkaitan dengan Pegawai Negeri Sipil (PNS), bahwa dikabarkan setidaknya ada PNS yang mengalami stroke akibat sesudah pensiun. Hal ini dikarenakan pensiunan mengalami gangguan penyesuaian terkait dengan faktor ekonomi karena terjadi perbedaan pendapatan yang diterima ketika masih bekerja dan tidak bekerja (Sopan, 2013). Selain itu, menurut Hamidah (2008), bahwa dari 30 pensiunan PNS yang diteliti, terdapat $46,6 \%$ pensiunan yang mengalami stres dengan kategori tinggi. Kondisi stres muncul ketika individu tidak mampu menerima kondisi pensiun dengan baik, sehingga muncullah gangguan psikologis dan ketidaksehatan mental seperti cemas, stres, dan bahkan mungkin depresi. Gejala post power syndrome juga akan terlihat pada pensiunan yang sebelumnya pernah memegang jabatan atau dari lingkungan pejabat struktural (Dinsi, 2006).

PNS merupakan bagian aparatur negara yang menjadi salah satu unsur terpenting dalam pemerintahan (Septhinna, Hakim, \& Wijaya, 2013). Berdasarkan data dari Badan Kepegawaian Daerah (2008), Batas Usia Pensiun (BUP) bagi pegawai negeri sipil adalah 56 tahun. Berdasarkan Peraturan Pemerintah Republik Indonesia nomor 19 tahun 2013 terjadi perubahan batas usia pensiun menjadi 58 tahun. BUP ini dapat saja diperpanjang menjadi 60 tahun, 63 tahun, 65 tahun, ataupun 70 tahun. Perpanjangan usia pensiun dari usia normal 58 tahun dapat terjadi karena berbagai alasan, salah satunya karena memangku suatu jabatan tertentu. Misalnya, pegawai yang memangku jabatan struktural eselon I atau eselon II dapat saja tetap memangku jabatan meski telah melewati BUP normal, yaitu 56 tahun. Hal ini juga berlaku bagi jabatanjabatan lain seperti hakim, guru, ataupun jabatan lainnya yang ditentukan oleh presiden. Jika ditinjau berdasarkan jumlah pensiunan, khususnya pensiunan PNS, saat ini terdapat hampir empat juta pensiunan PNS di seluruh Indonesia (Carik, 2012).

Deputi Menteri Pendayagunaan Aparatur Negara dan Sumber Daya Manusia Tasdik Kinanto (dalam Martono, 2012) menyatakan bahwa setiap tahun ada sekitar 110 ribu hingga 120 ribu individu PNS yang akan pensiun. Data tersebut mencakup seluruh wilayah negara Indonesia dan salah satu instansi adalah lingkungan Pemerintahan Provinsi Bali. Berdasarkan hasil studi pendahuluan di Badan Kepegawaian Daerah Provinsi Bali tahun 2014, didapatkan jumlah pejabat struktural yang pensiun pada tahun 2011 sebanyak 306 individu, tahun 2012 sebanyak 82 individu dan tahun 2013 sebanyak 68 individu.

Selama masa kerja, pejabat struktural identik dengan fasilitas pelayanan yang memadai, adanya asisten, relasi yang luas dan juga pendapatan yang tinggi, sehingga setelah masa pensiun fasilitas tersebut tidak didapatkan lagi (Rini, 2010). Liem \& Liem (dalam Eliana, 2003) menambahkan, selain 
kondisi psikologis, masa pensiun juga dapat memengaruhi kondisi fisiologis individu. Secara fisiologis, masa pensiun dapat menyebabkan masalah penyakit terutama gastrointestinal, gangguan saraf, dan berkurangnya kepekaan yang disebut retirement syndrome. Hal ini sejalan dengan hasil penelitian yang dilakukan oleh Handayani (2012) yaitu post power syndrome akan terlihat saat setelah memasuki masa pensiun, dengan mengalami gejala fisik berupa perubahan pada penglihatan, pendengaran serta sensorik motorik yang menurun setelah memasuki masa pensiun. Perubahan emosi juga muncul seperti stres, sedih serta penurunan harga diri juga dirasakan oleh pensiunan. Faktor yang menyebabkan individu mengalami post power syndrome yaitu akibat kehilangan jabatan yang berkaitan dengan kehilangan harga diri, kehilangan kewibawaan, kehilangan teman seprofesi dan juga kehilangan fasilitas dan penghasilan.

Perubahan kondisi psikologis seperti emosi yang kurang stabil, cemas, stres, dan bahkan depresi yang diakibatkan oleh masa pensiun, memerlukan penyesuaian diri (Parkinson, 1990). Proses penyesuaian diri pada masa pensiun merupakan proses yang sulit. Hal ini berkaitan dengan kehadiran masa pensiun yang dipandang sebagai permasalahan bagi individu penerimanya, seperti perubahan keadaan status sebelum pensiun dari kondisi yang aktif bekerja menjadi tidak bekerja, berkurangnya pendapatan, berkurangnya kontak sosial dengan teman sekerja dan dengan relasi dan individu lain di luar rumah. Oleh karena itu, pensiun dapat dikatakan menjadi bagian dari terputus atau berkurangnya kontak sosial. Kondisi inilah yang seakan-akan mendorong individu menghindar dari hadirnya masa pensiun, karena adanya ketakutan umum bahwa pensiun dapat mengganggu keamanan finansial dan kesehatan serta kontak sosial, sehingga masa pensiun dapat dikatakan sebagai penyesuaian diri yang sulit (Atchley dalam Eliana, 2003;Papalia dkk., 2007; Suardiman, 2011).

Studi pendahuluan dilakukan oleh peneliti pada bulan april 2014 kepada lima responden PNS pejabat struktural secara acak yang dilakukan melalui metode wawancara. Berdasarkan hasil wawancara diperoleh data bahwa dua dari lima responden mengatakan merasa bosan diam di rumah, merasa kesepian karena tidak ada relasi yang datang ke rumah dan merasa kurang perhatian dari keluarga. Dua responden lainnya mengatakan stres ketika tidak ada pekerjaan setelah pensiun. Sedangkan satu responden lainnya sering mengalami gangguan kesehatan seperti sulit tidur, nafsu makan menurun dan cepat lelah.

Berdasarkan hasil studi pendahuluan yang dilakukan peneliti menunjukkan bahwa masa pensiun merupakan masa yang penuh tantangan karena terjadi perubahan seperti dari aktif bekerja menjadi tidak bekerja, dari memiliki jabatan menjadi diam di rumah, dari mendapat penghasilan tinggi menjadi penghasilan yang lebih rendah, serta hilangnya relasi atau berkurangnya kontak sosial, yang berdampak pada munculnya gangguan secara fisiologis dan psikologis. Perubahan yang dialami pada masa pensiun membutuhkan penyesuaian diri, agar masa pensiun dapat berjalan dengan baik yaitu bebas dari stres, kecemasan dan kesepian.

Penyesuaian diri merupakan bentuk tingkah laku yang ditujukan untuk menanggulangi kebutuhan-kebutuhan yang ada di dalam diri individu. Tujuan dari penyesuaian diri adalah untuk mendapatkan keharmonisan antara tuntutan dari dalam diri dan lingkungan dimana individu tersebut berada. Individu yang memiliki penyesuaian diri yang lebih baik pada masa pensiun adalah individu yang sehat, memiliki pendapatan yang layak, aktif, berpendidikan baik, memiliki relasi sosial yang luas baik keluarga maupun teman-teman, dan merasa puas dengan kehidupan sebelum pensiun (Hurlock, 1980; Santrock, 2002).

Menurut Apsari (2012) dua tahun pertama sesudah pensiun disebut sebagai tahap reorientasi. Pada tahap ini individu akan mulai mengubah prioritasnya, aktivitas, hubungan, dan hidupnya. Pensiunan umumnya menyatakan bahwa tahap reorientasi ini merupakan tahap yang penuh dengan tantangan seperti kehilangan peran sosial, kehilangan kekuasaan, kontak sosial, harga diri rendah, tidak dapat memenuhi kebutuhan-kebutuhan tertentu dan pemasukan rendah, yang menyebabkan munculnya perasaan depresi, kecemasan, dan kebosanan akibat masa pensiun. Dalam melewati masa pensiun dan menjalani masa pensiun dengan tenang yaitu perasaan yang bebas dari perasaan depresi, kecemasan dan kebosanan, maka individu sangat memerlukan dukungan atau pendampingan dari individu terdekat (Hurlock, 1980).

Individu yang tengah menghadapi masa pensiun membutuhkan individu lain yang dapat membuat individu yang menjalani masa pensiun merasa dicintai dan diperhatikan sehingga dapat menyesuaikan diri dalam menjalani masa pensiun. Pentingnya penyesuaian diri pada masa pensiun dikarenakan saat menjalani masa pensiun, banyak terjadi perubahan. Oleh karena banyaknya terjadi perubahan pada masa pensiun maka sangat diperlukan dukungan sosial. Pernyataan ini diperkuat oleh hasil penelitian Kumalasari (2012) yang menunjukkan bahwa individu yang memiliki persepsi positif terhadap dukungan sosial, menunjukkan bahwa individu tersebut menyadari akan keadaan di sekitarnya dan juga menyadari diri individu itu sendiri, sehingga dapat menerima dan merasakan manfaat dukungan sosial. Dengan demikian, individu yang mendapatkan dukungan sosial yang baik, juga memiliki penyesuaian diri yang baik.

Adanya dukungan dan pengertian dari individuindividu terdekat seperti keluarga, akan sangat membantu pensiunan dalam menyesuaikan diri. Namun perilaku keluarga seperti menggerutu, menyindir, atau kurang perhatian akan mempersulit penyesuaian diri individu dalam menjalani masa 
pensiun (Hurlock, 1980; Rini, 2010). Pernyataan ini diperkuat oleh Sarafino (2007) yang menyatakan dukungan sosial mengacu pada memberikan kenyamanan, merawat dan menghargai. Pendapat senada juga diungkapkan oleh Sarason (dalam Smet, 2004) bahwa dukungan sosial adalah adanya transaksi interpersonal yang ditunjukkan dengan memberikan bantuan pada individu, dimana bantuan umumnya diperoleh dari individu yang memiliki arti bagi individu yang bersangkutan.

Dukungan sosial dapat berupa pemberian informasi seperti menyampaikan informasi tentang pensiun, sarana atau umpan balik tentang situasi dan kondisi individu yang dihadapi. Dukungan sosial juga dapat berupa dukungan instrumental seperti membantu untuk berpindah tempat, pemberian barang, makanan serta pelayanan. Dukungan penghargaan juga dapat ditunjukkan dalam bentuk pemberian penghargaan positif dan semangat pada individu. Dukungan emosional membuat individu memiliki perasaan nyaman, yakin, diperhatikan dan dicintai serta dukungan kelompok yang menyebabkan individu merasa menjadi bagian anggota dari suatu kelompok. Peranan dukungan sosial yang terdiri dari lingkungan keluarga dan lingkungan masyarakat sangat penting bagi penyesuaian diri individu yang memasuki masa pensiun. Tersedianya dukungan sosial dapat membantu individu menemukan jalan keluar dari masalah yang dihadapi dan membantu individu dalam menyesuaikan diri terhadap perubahan-perubahan yang terjadi, sehingga, hambatan dalam menghadapi pensiun dapat diatasi (Azizah, 2011; Suardiman, 2011).

Masa pensiun merupakan satu bagian dari masa kerja individu. Untuk menjalani masa pensiun yang baik, diperlukan penyesuaian diri sehingga individu yang dalam hal ini PNS pejabat struktural, dapat menghadapi perubahan-perubahan pada masa pensiun, termasuk perubahan fisiologis dan psikologis yang terjadi ketika akan menghadapi masa pensiun. Perubahan yang dialami seperti yang sebelumnya aktif bekerja menjadi tidak bekerja, berkurangnya pendapatan, berkurangnya kontak sosial dengan teman sekerja, relasi dan dengan individu-individu lain di luar rumah. Perubahan fisiologis yang terjadi yaitu penurunan kemampuan fisik dan penurunan kesehatan. Sedangkan perubahan psikologis yang cenderung dapat terjadi yaitu kesepian, terasing dari lingkungan, ketidakberdayaan, perasaan tidak berguna, kurang percaya diri, post power syndrom, emosi yang kurang stabil, cemas, stres, kesepian dan bahkan depresi yang diakibatkan oleh masa pensiun.

Oleh karena itu, dapat dikatakan bahwa diperlukan dukungan dan pengertian dari individu-individu terdekat yang akan sangat membantu pensiunan dalam menyesuaikan diri. Dukungan sosial mengacu pada dukungan informasi, dukungan instrumental, dukungan penghargaan, dukungan emosional dan dukungan kelompok. Dengan demikian, masa pensiun mendapatkan keharmonisan antara tuntutan dari dalam diri, dan lingkungan dimana individu tersebut berada. Berdasarkan pemaparan diatas, maka peneliti tertarik untuk melihat hubungan dukungan sosial dengan penyesuaian diri pada masa pensiun pejabat struktural di Pemerintahan Provinsi Bali.

\section{METODE}

\section{Variabel dan definisi operasional}

Variabel bebas pada penelitian ini adalah dukungan sosial dan variabel tergantung pada penelitian ini adalah penyesuaian diri masa pensiun. Adapun definisi operasional dari masingmasing variabel sebagai berikut:

\section{Dukungan Sosial}

Dukungan sosial merupakan bantuan nyata yang diterima dan dirasakan oleh pensiunan PNS yang dapat memberikan keuntungan emosional atau yang berpengaruh pada tingkah laku penerima dukungan berupa dukungan emosional, dukungan instrumental, dukungan penghargaan, dukungan informasi dan dukungan kelompok. Dukungan sosial diukur dengan skala dukungan sosial. Semakin tinggi skor yang diperoleh maka semakin tinggi tingkat dukungan sosial yang didapat.

2. Penyesuaian diri masa pensiun

Penyesuaian diri masa pensiun merupakan kemampuan pensiunan dalam menghadapi perubahan atau tekanan sehingga lebih dapat mengekspresikan perasaan dan memahami perubahan yang dialami baik yang bersumber dari diri sendiri ataupun lingkungan, lebih positif melihat diri sendiri yang kemudian berdampak pada kesuksesan dalam menjalin hubungan baik dengan individu lain. Penyesuaian diri masa pensiun diukur dengan Skala Penyesuaian Diri Masa Pensiun. Semakin tinggi skor yang diperoleh maka semakin tinggi tingkat penyesuaian diri masa pension

\section{Karakteristik responden}

Populasi dalam penelitian ini adalah remaja akhir Populasi yang digunakan pada penelitian ini adalah seluruh PNS pejabat struktural di pemerintahan Provinsi Bali yang sudah pensiun tahun 2012 dan tahun 2013 dengan jumlah 150 individu. Sampel adalah sebagian dari populasi yang memiliki sifat dan ciri yang sama dengan populasi karena ditarik dari populasi dengan menggunakan teknik sampling tertentu yang dapat dipertanggungjawabkan (Purwanto, 2010). Adapun sampel yang digunakan dalam penelitian ini adalah bagian dari jumlah karakteristik yang dimiliki populasi yaitu pensiunan PNS pejabat struktural di pemerintahan Provinsi Bali yang sudah pensiun dari tahun 2012 dan 2013. 


\section{Tempat penelitian}

Proses pengambilan sampel ini dilakukan di Pemerintahan Provinsi Bali, pada PNS pejabat struktural yang sudah pensiun dari tahun 2011-2012. Penelitian ini dilaksanakan pada bulan Oktober 2014.

\section{Alat ukur}

Alat ukur pada penelitian ini menggunakan dua skala yaitu Skala Dukungan Sosial dan Skala Penyesuaian Diri Masa Pensiun. Skala Dukungan sosial dalam penelitian ini disusun sendiri oleh peneliti berdasarkan teori dari Azizah (2011) dan Skala Penyesuaian Diri Masa Pensiun pada penelitian ini disusun berdasarkan teori dari Runyon \& Haber (1984) dengan menggunakan model skala likert. Skala Dukungan Sosial terdiri dari 28 aitem pernyataan dan Skala Penyesuaian Diri Masa Pensiun terdiri dari 21 aitem pernyataan. Skala dukungan sosial dan penyesuaian diri masa pensiun disajikan dalam bentuk pernyataan favorable dan unfavorable yang nantinya skor akan diberikan antara 1 sampai 4. Pada skala dukungan sosial dan skala penyesuaian diri masa pensiun terdapat 4 respon pernyataan yaitu: Sangat Tidak Setuju (STS), Tidak Setuju (TS), Setuju (S), Sangat Setuju (SS). Hasil dari pengujian validitas skala dukungan sosial didapatkan hasil korelasi skor-skor aitem dengan skor total aitem berkisar antara 0,307 hingga 0,786. Hasil pengujian reliabilitas skala dukungan sosial pada saat uji coba adalah 0,910 yang menunjukan bahwa skala ini mampu mencerminkan $91,0 \%$ variasi yang terjadi pada skor murni sampel yang bersangkutan sehingga alat ukur layak digunakan sebagai alat ukur untuk mengukur dukungan sosial.

Pada skala penyesuaian diri masa pensiun, diketahui hasil uji validitas korelasi skor-skor aitem berkisar antara 0,341 hingga 0,771. Hasil pengujian reliabilitas skala penyesuaian diri masa pensiun pada saat uji coba adalah 0,894 yang menunjukan bahwa skala ini mampu mencerminkan $89,4 \%$ variasi yang terjadi pada skor murni sampel yang bersangkutan sehingga alat ukur layak digunakan sebagai alat ukur untuk mengukur penyesuaian diri masa pensiun.

\section{Teknik analisis data}

Pada penelitian ini metode analisis data yang digunakan adalah analisis statistik dan untuk menganalisis data penelitian yang telah diperoleh peneliti menggunakan korelasi product moment dengan bantuan program statistik Statistical Package for Social Science (SPSS) versi 17. Sebelum melakukan korelasi product moment peneliti melakukan uji normalitas dan uji linieritas. Pada penelitian ini uji normalitas dilakukan dengan menggunakan Kolmogorov Smirnov dan uji linearitas menggunakan Compare Means.

\section{HASIL PENELITIAN}

\section{Karakteristik Subjek}

Berdasarkan hasil data karakteristik subjek, diketahui subjek pada penelitian ini berjumlah 150 individu dengan lakilaki sebanyak 85 individu dan perempuan sebanyak 20 individu dengan rentang umur 57-58. Dan memegang jabatan eselon I,II,III dan IV.

\section{Deskripsi Data Penelitian}

\begin{tabular}{lcc}
$\begin{array}{l}\text { Tabel } 1 . \\
\text { Desknipsi statistik data penelitian }\end{array}$ & & \\
\hline Variabel & Mean Teoretis & Mean Empiris \\
\hline Dukungan Sosial & 70 & 89,64 \\
Penyesuaian Diri Pada Masa & 52,5 & 66,92 \\
Pensiun & & \\
\hline
\end{tabular}

Berdasarkan analisis data dari variabel dukungan sosial didapatkan hasil mean teoretis sebesar 70, sedangkan mean empiris sebesar 89,64. Hasil tersebut menunjukan mean empiris lebih besar dari mean teoritis pada variabel dukungan sosial, dan memiliki arti bahwa rata-rata responden memiliki tingkat dukungan sosial yang tinggi.

Pada variabel penyesuaian diri pada masa pensiun diperoleh mean teoretis sebesar 52,5, sedangkan mean empiris sebesar 66,92. Berdasarkan hasil tersebut maka mean empiris lebih besar dari mean teoritis pada variabel penyesuaian diri masa pensiun, dan memiliki arti bahwa ratarata responden memiliki tingkat penyesuaian diri pada masa pensiun yang baik.

\section{Uji Asumsi}

Tabel 2

Hasil uji normalitas

\begin{tabular}{lccccccc}
\hline & \multicolumn{3}{c}{ Kolmogorov-Smirnova $^{a}$} & \multicolumn{3}{c}{ Shapiro-Wilk } \\
& Statistic & Df & Sig. & Statistic & Df & Sig. \\
\hline Dukungan sosial & .067 & 105 & .200 & .982 & 105 & .170 \\
$\begin{array}{l}\text { Penyesuaian diri pada } \\
\text { masa pensiun }\end{array}$ & .088 & 105 & .052 & .979 & 105 & .090 \\
\hline
\end{tabular}

Hasil Uji Normalitas pada tabel 2, pada kolom kolmogorov-smirnov nilai sig. data dukungan sosial dan tingkat Penyesuaian diri pada masa pensiun yaitu 0,200 $(p=0,200)$. Nilai $p=0,200$ menunjukkan bahwa data dukungan sosial berdistribusi normal dan penyesuaian diri pada masa pensiun berdistribusi normal yaitu $0,052(\mathrm{p}=0,052)(\mathrm{p}<0,05)$ 
Tabel 3.

Hasil uji linieritas

\begin{tabular}{lcccc}
\hline & & & F & Signifikansi \\
\hline Dukungan sosial & Between & (Combined) & 5,712 & 0,000 \\
Penyesuaian diri & Groups & Linearity & 123,820 & 0,000 \\
& & $\begin{array}{c}\text { Derivation from } \\
\text { Linearity }\end{array}$ & 1,494 & 0,078 \\
& & & \\
\hline
\end{tabular}

Dari hasil uji linearitas pada Tabel 3, menunjukkan bahwa hubungan dukungan sosial dengan penyesuaian diri pada masa pensiun adalah linier, karena memiliki probabilitas (p) sebesar 0,000 atau memiliki taraf signifikansi untuk linieritas lebih kecil dari 0,05 ( $p<0,05)$ sehingga dapat dikatakan bahwa hubungan antara variabel dukungan sosial dengan penyesuaian diri masa pensiun telah menunjukkan adanya garis lurus.

Berdasarkan uji normalitas dan uji linieritas yang telah dilakukan, diperoleh hasil bahwa data penelitian bersifat normal dan linier sehingga penelitian ini menggunakan analisis korelasi Pearson Product Moment.

\section{Uji Hipotesis}

Berikut merupakan hasil uji korelasi product moment variabel dukungan sosial dengan variabel penyesuaian diri masa pensiun:

\begin{tabular}{|c|c|c|c|}
\hline & & $\begin{array}{c}\text { Dukungan } \\
\text { sosial }\end{array}$ & $\begin{array}{c}\text { Penyesuaian } \\
\text { diri }\end{array}$ \\
\hline \multirow{3}{*}{$\begin{array}{l}\text { Dukungan } \\
\text { Sosial }\end{array}$} & Pearson Correlation & 1 & $.717\left(^{\star \star}\right)$ \\
\hline & Sig. (2-tailed) & & .000 \\
\hline & $\mathrm{N}$ & 105 & 105 \\
\hline \multirow{3}{*}{$\begin{array}{l}\text { Penyesuaian } \\
\text { Diri }\end{array}$} & Pearson Correlation & $.717^{(* *)}$ & 1 \\
\hline & Sig. (2-tailed) & .000 & \\
\hline & $\mathrm{N}$ & 105 & 105 \\
\hline
\end{tabular}

Berdasarkan table 4 hasil uji korelasi product moment dari Pearson, terlihat bahwa nilai Sig. (2-tailed) untuk variabel dukungan sosial dan variabel penyesuaian diri pada masa pensiun adalah 0,000 atau lebih kecil dari 0,05 ( $p<0,05)$. Hal ini menyatakan bahwa ada hubungan antara dukungan sosial dengan penyesuaian diri.

Untuk melihat arah hubungan dan seberapa kuat hubungan dari dukungan sosial dengan penyesuaian diri pada masa pensiun, dapat dilihat dari nilai Pearson Correlation. Berdasarkan tabel hasil uji korelasi Pearson, diperoleh nilai $r=$ 0,717. Nilai $r$ sebesar 0,717 tersebut tidak terdapat tanda negatif, sehingga dapat dikatakan bahwa dukungan sosial memiliki hubungan yang searah dan positif dengan penyesuaian diri pada masa pensiun. Pengertian dari hubungan yang searah dan positif adalah jika terjadi peningkatan dalam dukungan sosial, maka kecenderungan penyesuaian diri pada masa pensiun juga akan mengalami peningkatan. Jika dukungan sosial mengalami penurunan, maka kecenderungan penyesuaian diri pada masa pensiun juga akan mengalami penurunan.

\section{PEMBAHASAN DAN KESIMPULAN}

Berdasarkan paparan hasil penelitian dan hasil analisis di atas dengan menggunakan teknik korelasi product moment dari Pearson, pengujian hipotesis tersebut dapat dibuktikan dengan adanya nilai Sig. (2-tailed) untuk variabel dukungan sosial dan variabel penyesuaian diri pada masa pensiun adalah 0,000 atau lebih kecil dari 0,05 ( $\mathrm{p}<0,05)$. Dapat dikatakan bahwa H0 ditolak dan Ha diterima sehingga "ada hubungan yang positif dan signifikan antara dukungan sosial dengan penyesuaian diri pada masa pensiun pejabat struktural di Pemerintahan Provinsi Bali”.

Selain itu, dukungan sosial dengan penyesuaian diri pada masa pensiun juga memiliki hubungan yang searah dan positif serta memiliki hubungan yang kuat. Hal tersebut terbukti dari hasil pengujian hipotesis yang menghasilkan nilai koefisien korelasi sebesar 0,717. Tidak terdapatnya tanda negatif pada koefisien korelasi, menyatakan bahwa "dukungan sosial memiliki hubungan yang searah dan positif dengan penyesuaian diri pada masa pensiun". Semakin tinggi dukungan sosial, maka semakin tinggi pula penyesuaian diri pada masa pensiun yang dimiliki pensiunan pejabat struktural. Jika semakin rendah dukungan sosial, maka semakin rendah pula penyesuaian diri pada masa pensiun yang dimiliki pensiunan pejabat struktural. Nilai koefisien korelasi sebesar 0,717 termasuk ke dalam golongan korelasi yang kuat, menyatakan bahwa "dukungan sosial memiliki hubungan yang kuat dengan penyesuaian diri pada masa pensiun yang dimiliki oleh pejabat struktural di Pemerintahan Provinsi Bali”.

Hasil penelitian sesuai dengan hipotesis penelitian karena dukungan sosial merupakan faktor yang penting yang mempengaruhi penyesuaian diri pada masa pensiun (Setyaningsih \&Mu'in, 2013). Hubungan yang signifikan dan positif antara dukungan sosial dengan penyesuaian diri pada masa pensiun juga ditemukan dalam penelitian Ermayanti \& Abdullah (2012). Pensiunan yang mempersepsikan dukungan sosial secara positif, dapat diartikan bahwa penyesuaian diri yang terjadi pada masa pensiun sesuai dengan apa yang dirasakan dan berarti bagi kenyamanan individu dalam menjalani masa pensiun. Dukungan sosial juga memiliki peranan penting bagi seseorang yang mengalami masa transisi penting dalam kehidupannya seperti memasuki masa pensiun (Hurlock, 1980). 
Schwartz (dalam Hurlock, 1980), menyatakan bahwa masa pensiun merupakan akhir dari pola hidup individu dalam bekerja atau dapat pula disebut sebagai masa transisi ke pola hidup yang baru. Pensiun selalu menyangkut perubahan peran, perubahan keinginan dan nilai, serta perubahan secara keseluruhan terhadap pola hidup setiap individu. Dalam menghadapi masa pensiun, individu umumnya mengeluarkan berbagai macam reaksi, yaitu ada tiga sikap ataupun reaksi yang umumnya muncul ketika individu memasuki masa pensiun yaitu menerima, terpaksa menerima, dan menolak.

Sikap penolakan terhadap masa pensiun umumnya terjadi karena individu yang pensiun tidak mau mengakui bahwa dirinya sudah harus pensiun, takut tidak dapat memenuhi kebutuhan-kebutuhan tertentu, takut kehilangan peran sosial di masyarakat, kehilangan kekuasaan, kontak sosial dan harga diri rendah, stres, depresi, cemas dan emosi yang kurang stabil (Rakhmat \& Budiman, 2010). Sehingga, untuk menghadapi masalah dari perubahan yang dirasakan tersebut, pensiunan berupaya mencari pemecahan atau jalan keluar dengan cara menyesuaikan diri dengan kondisi yang dialami.

Schneiders (1964), menjelaskan bahwa penyesuaian diri merupakan perubahan yang terjadi dalam diri individu dan lingkungan sekitar untuk mencapai hubungan yang memuaskan dengan individu lain dan lingkungan sekitar. Individu yang menjalani masa pensiun membutuhkan penyesuaian diri agar ketika menjalani masa pensiun dapat berlangsung dengan tenang dan nyaman. Masa pensiun yang dijalani dengan nyaman adalah masa pensiun yang bebas dari perasaan depresi, kecemasan dan kebosanan (Papalia dkk., 2007; Suardiman, 2011). Untuk tercapainya penyesuaian diri yang baik dibutuhkan suatu dukungan sosial yang merupakan pemberian kenyamanan fisik dan psikologis yang didapat melalui pengetahuan bahwa individu dicintai, diperhatikan dan dihargai oleh individu lain (Suardiman, 2011).

Dukungan sosial merupakan dukungan yang diterima individu penerima dukungan sosial dapat berupa kehadiran dan hal-hal yang dapat memberikan keuntungan emosional atau yang berpengaruh pada tingkah laku individu penerima dukungan sosial. Dukungan sosial dapat memberikan kenyamanan, perhatian serta penghargaan yang diterima individu dari individu lain ataupun dari kelompok (Sarafino, 2007; Taylor dkk., 2009; Azizah, 2011). Pandangan mengenai dukungan sosial merujuk pada bagaimana dukungan sosial dapat memberikan pengaruh bagi pensiunan PNS pejabat struktural yang mengalami berbagai perubahan dalam diri, dan lingkungan sekitar.

Tersedianya dukungan sosial terhadap penyesuaian diri dalam masa pensiun dapat membantu individu menemukan jalan keluar dari masalah yang dihadapi dan membantu individu dalam menyesuaikan diri terhadap perubahan yang terjadi, sehingga hambatan dalam menghadapi pensiun dapat diatasi (Kumalasari, 2012). Selain itu juga dukungan sosial memiliki dampak positif terhadap penyesuaian diri masa pensiun yaitu adanya dukungan dari individu lain terhadap individu yang menghadapi masa pensiun dapat menjadi merasa dicintai dan diperhatikan bagi individu penerima dukungan.

Dalam penelitian ini, diperoleh angka sumbangan efektif sebesar 0,514. Hal ini berarti sumbangan variabel dukungan sosial terhadap variabel penyesuaian diri pada masa pensiun adalah sebesar $51,4 \%$, sedangkan sumbangan selain variabel dukungan sosial terhadap penyesuaian diri pada masa pensiun sebesar $48,6 \%$, yang diperoleh dari faktor-faktor lain. Terdapat lima faktor yang mempengaruhi penyesuaian diri pada masa pensiun yaitu kondisi fisik, perkembangan dan kematangan, keadaan psikologis, keadaan lingkungan, serta agama dan budaya (Schneiders, 1964).

Berdasarkan analisis data dari variabel dukungan sosial memiliki rata-rata teoretis sebesar 70 dan rata-rata empiris sebesar 89,64. Angka rata-rata teoretis dan empiris menunjukkan bahwa rata-rata responden penelitian yaitu pensiunan PNS pejabat struktural di Pemerintahan Provinsi Bali memiliki tingkat dukungan sosial yang tinggi, karena rata-rata empiris lebih tinggi dari pada rata-rata teoretis. Hasil penelitian ini menunjukkan tingkat penyesuaian diri masa pensiun pada responden, tergolong tinggi yang ditunjukkan dengan rata-rata empiris lebih besar yaitu 66,92 dibandingkan dengan rata-rata teoritis yaitu 5,30. Angka rata-rata teoretis dan empiris menunjukkan bahwa rata-rata responden penelitian yaitu pensiunan PNS pejabat struktural di Pemerintahan Provinsi Bali memiliki tingkat penyesuaian diri yang tinggi, karena rata-rata empiris lebih tinggi dari pada rata-rata teoretis.

Berdasarkan hasil kategorisasi responden pada skala dukungan sosial, menunjukkan bahwa $81,9 \%$ dari 105 responden penelitian memiliki dukungan sosial yang tinggi, sisanya sebanyak $15,2 \%$ berada pada kategori rendah dan 2,9\% memiliki dukungan sosial sangat tinggi. Maka dapat diartikan bahwa pensiunan memiliki dukungan sosial yang tinggi. Tingkat dukungan sosial yang tinggi menunjukan arti individu menerima dukungan sosial yang positif dari lingkungan sekitar. Hasil kategorisasi responden pada skala penyesuaian diri menunjukkan bahwa $61,1 \%$ dari 105 responden penelitian, memiliki kategori penyesuaian diri pada masa pensiun yang tinggi. Sisanya adalah 33,3\% memiliki penyesuaian diri yang sangat tinggi dan 4,8\% memiliki penyesuaian diri dengan kategori sedang. Maka dapat dikatakan bahwa pensiunan pada penelitian ini memiliki penyesuaian diri pada masa pensiun dari katagori sedang hingga sangat tinggi. Tingkat penyesuaian diri pada masa pensiun yang tinggi berarti individu dapat mencapai kepuasan dalam memenuhi kebutuhan, mengatasi kecemasan, depresi, frustasi dan konflik (Ghufron \& Risnawita, 2012). 
Tingkat dukungan sosial yang tinggi pada responden dapat ditinjau dari latar belakang responden penelitian. Responden pada penelitian ini sebagian besar merupakan masyarakat Bali. Masyarakat Bali cenderung mengikuti tradisi yaitu masyarakat yang kolektif. Kolektivitas adalah keterlibatan individu untuk bergabung di dalam suatu kelompok. Masyarakat yang kolektif cenderung menyelesaikan masalah bersama-sama, sehingga kebersamaan ini dapat membuat individu memerlukan orang lain dan saling bergantung kepada individu lain. Individu yang saling bergantung secara otomatis akan selalu memberikan dukungannya, terutama bila terjadi masalah atau disaat individu tersebut memerlukan dukungan sosial (Himawan, 2014). Hal ini diperkuat dengan hasil penelitian data demografi yang menunjukan bahwa aktivitas yang cenderung dilakukan oleh pensiunan adalah aktivitas yang dilakukan secara bersama-sama seperti kegiatan adat, kegiatan keagamaan, kegiatan sosial dan arisan.

Tingkat penyesuaian diri yang tinggi pada responden dapat dianalisis melalui latar belakang aktivitas yang diikuti saat ini oleh responden. Pada penelitian ini semua responden mengikuti berbagai macam kegiatan. Kegiatan yang paling banyak diikuti oleh responden adalah kegiatan keagamaan yaitu sebanyak 44,44\%. Kegiatan agama dapat memberikan jalan pada individu untuk mencapai rasa aman, tidak takut atau cemas dalam menghadapi persoalan hidup. Kegiatan keagamaan penting dilaksanakan bagi pensiunan untuk mengisi hari-harinya agar dapat mengurangi konflik, frustasi dan ketegangan fisik lainnya (Suardiman, 2011). Oleh karena itu, dengan mengikuti kegiatan keagamaan dapat membuat individu memiliki penyesuaian diri pada masa pensiun yang baik.

Berdasarkan dari data deskripsi demografi responden yaitu jenis kelamin, tidak ada perbedaan antara jenis kelamin laki-laki dan perempuan dengan penyesuaian diri pada masa pensiun PNS pejabat struktural. Hal ini dibuktikan dengan uji komparasi independent sample t-tes, yang menunjukan skor probabilitas sebesar 0,441 ( $\mathrm{p}>0.05$ ) (Lampiran 8). Artinya tidak ada perbedaan antara jenis kelamin dan penyesuaian diri pada masa pensiun. Hal ini sejalan dengan penelitian Arita \& Makhrurrozi (2008) yang menunjukan bahwa tidak ada perbedaan antara penyesuaian diri pada masa pensiun baik pada laki-laki maupun perempuan karena laki-laki dan perempuan sama-sama memiliki kemampuan penyesuaian diri yang baik. Perempuan memiliki kecenderungan lebih mampu untuk merawat diri sendiri dan memperoleh dukungan sosial yang lebih besar dibanding laki-laki. Selain itu, adanya pandangan mengenai peran laki-laki yang merupakan sebagai pekerja keras dan pencari nafkah bagi keluarga yang menjadikan laki-laki puas terhadap pekerjaan sebelumnya (Sari, 2010). Selanjutnya, tidak ada perbedaan antara usia terhadap penyesuaian diri pada masa pensiun. Hal ini terlihat dari independent sample t-tes, yang menunjukan skor probabilitas sebesar 0,812 ( $\mathrm{p}>0.05$ ), yang artinya bahwa tidak ada perbedaan antara penyesuaian diri pada masa pensiun dengan usia (lampiran 8).

Berdasarkan dari data demografi yaitu eselon, ditemukan bahwa tidak ada perbedaan antara eselon dengan penyesuaian diri pada masa pensiun. Hal ini dibuktikan dengan uji komparasi dengan teknik one way anova, yang menunjukan skor probabilitas sebesar 0,822 ( $\mathrm{p}>0.05)$ (lampiran 8). Hal ini diperkuat oleh hasil penelitian Kusumarini (2006), yaitu Pegawai Negeri Sipil eselon I,II,III dan IV mempunyai sikap dan persepsi yang baik untuk dapat menyesuaikan diri dengan baik pada masa pensiun. Sehingga dapat dikatakan bahwa tidak ada perbedaan antara eselon I,II,II dan IV dengan penyesuaian diri pada masa pensiun.

Selanjutnya, berdasarkan data deskripsi demografi pada aktivitas yang diikuti saat ini oleh pensiunan menunjukan bahwa 44,44 \% responden mengikuti kegiatan keagamaan pada saat mengisi waktu luang di masa pensiun. Yang dimaksud dengan aktivitas yang diikuti saat ini merupakan aktivitas yang diikuti oleh pensiunan untuk mengisi waktu luang. Hal ini sejalan dengan Suardiman (2011), yang mengatakan bahwa seharusnya ketika pensiun adalah melakukan berbagai kegiatan untuk mengisi waktu luang. Ada perubahan sifat yang drastis yang dulunya sibuk bekerja menjadi tidak bekerja. Pensiunan merasakan ada sesuatu yang hilang pada dirinya yaitu kesibukan. Oleh karena itu menciptakan kesibukan sangat penting bagi para pensiunan.

Pada penelitian ini aktivitas keagamaan merupakan aktivitas yang paling banyak dilakukan oleh pensiunan dalam menjalani masa pensiun. Aktivitas keagamaan merupakan kegiatan positif yang bertujuan untuk mendekatkan diri kepada Tuhan Yang Maha Esa. Banyak pensiunan yang beranggapan bahwa sudah waktunya untuk melakukan kegiatan keagamaan. Aktivitas agama pada masa pensiun ini merupakan tahap kesadaran yang nantinya dapat mencapai ketenangan dalam menghabiskan waktu luang (Suardiman, 2011).

Berdasarkan pemaparan pembahasan hasil penelitian, dapat dikatakan bahwa penelitian ini telah memenuhi tujuannya yaitu mengetahui hubungan positif dan signifikan antara dukungan sosial dan penyesuaian diri pada PNS pejabat struktural di Pemerintahan Povinsi Bali. Hal tersebut juga menunjukkan bahwa semakin tinggi dukungan sosial yang didapat maka semakin meningkat penyesuaian diri pada masa pensiun pejabat struktural di Pemerintahan Provinsi Bali. Jika dilihat dari dukungan sosial pensiunan PNS pejabat struktural di Pemerintahan Provinsi Bali menunjukan bahwa mereka mendapatkan dukungan berupa dukungan emosional, dukungan penghargaan, dukungan instrumental, dukungan informasi dan dukungan kelompok yang memadai. Pensiunan PNS pejabat struktural juga tergolong individu-individu yang 
berhasil menyesuaikan diri saat berhadapan pada masa pensiun.

\section{DAFTAR PUSTAKA}

Arita, H. F., \& Makhrurrozi, M. (2008). Perbedaan penyesuaian diri pada masa pensiun berdasarkan jenis kelamin. Jakarta: Jurnal Universitas Gunadarma, 01, 1-8.

Apsari, Y. F. (2012). Pengembangan model persiapan pensiun bagi karyawan non pendidikan di universitas x. Surabaya :Jurnal Psikologi Universitas Katolik Widia Mandala Surabaya, 02, hal. 68-80.

Azizah, L. M. (2011).Keperawatan lanjut usia. Yogyakarta: Grahallmu.

Baruch, Yehuda. (2004). Managing Careers - theory and practice. London: Prentice Hall

Carik. (2012). Pegawai negeri sipil. Diakses pada Desember 2, 2013 http://birokepegawaian.com/article/122501overview\#a0104

Dinsi, V. (2006). Ketika pensiun tiba. Jakarta : Wijayata Media Utama.

Eliana, R. (2003). Konsep diri pensiunan. Sumatra Utara: USU digital library,02, 158-162

Ermayanti, S., \& Abdullah, S. M. (2012). Hubungan antara persepsi terhadap dukungan sosial dengan penyesuaian diri pada masa pensiun. Yogjakarta: Jurnal Wangsa Manggala , 01.

Ghufron,N.,\& Risnawita, R. (2012). Teori-teori psikologi. Jogjakarta: AR-Ruzz Mediz

Hamidah. (2008). Pengembangan model persiapan pensiun untuk meningkatkan kesejahteraan psikologis dan menurunkan stres menghadapi pensiun Surabaya: Airlangga University Library, 02.

Handayani, Y. (2012). Post power syndrome pada pegawai negeri sipil yang mengalami masa pensiun. Jogjakarta: Jurnal Psikologi Fakultas Gunadarma, 03, 187-192.

Himawan, W. (2014). Perubahan budaya pariwisata bali melalui karya seni lukis. Bandung: Jurnal of urban society art, 14, 78-88.

Hurlock, E. B. (1980). Suatu pendekatan sepanjang rentang kehidupan. Jakarta: Penerbit Erlangga.

Isnawati, D., \& Suhariadi, D. H. (2013). Hubungan dukungan sosial dengan penyesuaian diri masa persiapan pensiun pada karyawan pt. Pupuk kaltim. Surabaya : Jurnal Psikologi Industri dan Organisasi, 02.

Kumalasari, F. (2012). Hubungan antara dukungan sosial dengan penyesuaian diri remaja di panti asuhan. Jawa tengah: Jurnal Psikologi Pitutur, 01.

Papalia, D. E., Sterns, H. L., Feldman, R. D., \& Camp, C. J. (2007). Adult Development and Aging (3th ed.). McGraw-Hill.

Parkinson, C.N. (1990). Masa pensiun yang bahagia.Jakarta :Binarupa Aksara.

Peraturan Pemerintahan Nomer 19 Tahun 2013 Tentang Perubahan Keempat Atas Peraturan Pemerintah Nomer 32 Th 1979 Tentang Pemberhentian Pegawai Negeri Sipil.

Purwanto. (2010). Metodologi Penelitian Kuantitatif :Untuk Psikologi dan Pendidikan. Yogyakarta : Pustaka Pelajar.
Rakhmat, P. D., \& Budiman, N. (2010). Permasalahan-permasalahan pada masa tua.

Rini, F. (2010).Pensiun dan pengaruhnya. Jakarta. Diakses pada Desember 2, 2013. Available: http://www.epsikologi.com/artikel/lanjut-usia/pensiun-dan-pengaruhnya.

Runyon \& Haber. A. (1984). Psycology of adjustment. Illinois: The Dorsey Pres

Santrock, J.W. (2002). Remaja. Jakarta : Erlangga

Sarafino, E. P. (2007). Health psychology biopsychosocial interactions (ed. 6). Canada : John Milley and Sons Inc.

Sari, H. S. (2010). Pengaruh dukungn sosial dan kepribadian terhadap penyesuaian diri pada masa pensiun. Jurnal Universitas Islam, 01, 1-9.

Scheineders, A.A. (1964). Personal adjustment and mental health. New York : Holt, reinhart \&Winston Inc.

Seligman, Linda (1994). Developmental career counseling and assessment (ed. 2). London: SAGE

Setyaningsih, S., \& Mu'in, M. (2013). Dukungan sosial dan tingkat kecemasan pada kelompok pekerja pns yang menghadapi masa pensiun. Jurnal Keperawatan Komunitas , 01, 116-121.

Septhinna, E., Hakim, A., \& Wijaya, A. F. (2013). Proses rekrutmen sumber daya aparatur dinas pendidikan (studi kasus badan kepegawaian daerah kota malang). Jurnal Administrasi Publik (JAP), 02, 165-173.

Suardiman, S. P. (2011).Psikologi lanjut usia. Yogjakarta: Gadjah Mada University Press.

Sugiyono. (2013). Metode Penelitian Kuantitatif Kualitatif dan R\&D. Bandung: Alfabeta.

Smet, Bart. (2004). Psikologi Kesehatan. Jakarta: PT Gramedia Widia sarana Indonesia.

Sopan, S. (2014). Dikabarkan stroke, waryono berlibur ke raja ampat. Dikses pada Januari 20, 2014. Available:http;//huttestijl.com/2014/01/dikabarkan-stroke-waryono-berliburke.html?m=1

Taylor, S. E., Peplau, L.A., \& Sears, D.O. (2009). Psikologi sosial (ed. 12). Jakarta: Kencana 